\title{
集落整備と都市計画
}

\section{柳 沢 厚*}

I 集落と都市計画制度のかかわり

一昨年制定された集落地域整備法については後 述する。この制度を除けば, 現行都市計画制度が 市街化調整区域内の農村集落, ないし都市近郊集 落にかかわろ局面は, 晨村計画論の視点からすれ ば, いわば「加害者側」からの関与としてとらえ られる。

その関与, すなわち開発行為，または建築行為 のあり様は，その性格から 4 つの䉕ちゅうに分け られる。

第一は，既存宅地における建築行為である。こ の制度は昭和49年の議員立法による法改正によっ て遄入されたものであり，一定の条件を満たす既 存集落内の宅地における建築行為は許可なしに行 うことができるという趣旨の制度である。一見す ると当然と思えるこの制度は，次の二つの点で極 めて問題のあるものとなっている。

(1)“一定の条件”の把握, および判定に安全性 を欠き，昨年は認められなかった土地が今年は可 となることが少なからずあり，調整区域内規制の 信頼を大きく裹切っている。（時によっては，不 動産業者にとって鍊金術のような効果をもたらす ことがある)

(2)調整区域内は，その趣旨からすれば，一般の 開発は禁止され一定のものが認められるとして も，十分に条件が付された上で可能となるもので あるにもかかわらず, 既存宅地における建築行為
については何ら条件を付すこともできないばかり か, 建築基準も極めて紸やかなものとなってい る。(用途地域=無指定, 建ぺい伎70\%, 容積率 $400 \%$ ，用途制限なし）

第二は, 開発許可を要さない開発行為である。 その主要なものは, 農林漁業者の住宅, 生産用施 設および学校, 病院, 役場等の公共公益施設のた めの開発行為である。これに関しては, 農業者の 生産施設として建設される「農業用倉庫」の転用 がしばしば問題になるほか, 公共公益施設の無神 経な立地を問題視する意見も多い。

第三は，その開発行為の目的となる建築物の性 格上調整区域内の立地に妥当性があるとして許可 されるものである。たとえば, 調整区域内の居住 者のための日用品販売店舗, 調整区域内の鉱物資 源や観光資源の有効利用のために必要な建築物, 市街化区域内の立地が不適当な危険物の貯蔵, ま たは処理施設などである。この籍ちゅうには，有 名な農家の二・三男の分家住宅等も含まれ，過 去,これらが適法とは言いがたい状態で，農村集 落に多数建設されてきたことは周知のとおりであ る。

第四は，大規模な計画的開発で十分な良質の宅 地整備を見込むことができるということを理由と して許可されたものである。これはいわゆる20ha 開発である。昭和58年の政令改正により都道府 県，または政令指定市の規制によって 5 haまで開 発規模を下げることとなったが, いずれにしても これは相当にコントロールされた，あるいはされ 得る開発であり, 既存集落とのコミュニティーの

\footnotetext{
*国土開発技術研究センター
} 
隔絶等の問題はあるが, 前三者とは加害の質が異 なり、ここでの討議の対象から除外してよいと考 えられる。

\section{II 集落地域整備法の概要}

第一から第三の開発行為，および建筑行為が集 落塄境（生産および生活環境）の質的低下の主要 な原因となっているためこれを規制し，あるいは 秩序だてる必要があること，および一方で集落の 維持, 振興のためにはある程度の積極的な整備・

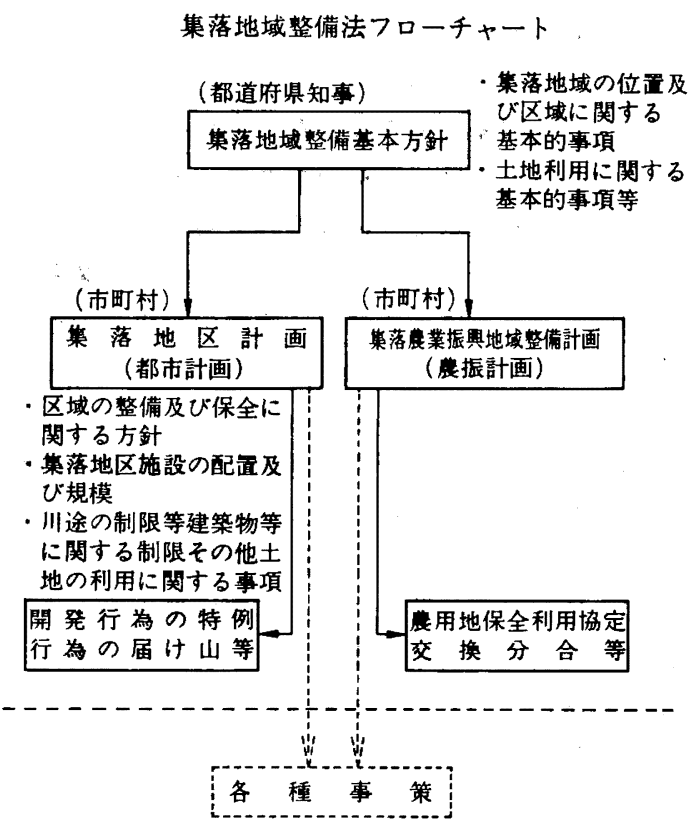

開発が必要であることこの二つの要請に応える ため, 開発の可能性を大きくする一方，きめ細や かな土地利用のコントロールをできるようにす る。これが集落地域整備法の都市計画側からの意 味である。

具体的には，図に示したとおり，まず「集落地 域整備基本方針」を定める。この主たる機能は, この法律を適用する集落を維持することである。 ある集落がこの方針において適用対象とされる と, その集落には「集落地区計画」及び「集落農 業振興地域整㣁計画」を定めることが可能となる。

集落地区計画を的確に定めることが都市計画の 主要な関心事であるが,この計画の機能は次の三 点に集約することができる。

(1)計画区域内ではほほ市街化区域内と同様の開 発が可能となる一開発に至るまでの手続きは異な るが実質的规制は市街化区域なみになるため，こ の計画を定めることは，いわば“ミニ線引き”の 意味あいを持っている。

(2)建築物の用途・形態等についてコントロール が可能となる一市街化区域内の地区計画と同様, 建築物の用途, 高さ, 建ぺい率, 壁面位置, 意 匠，唕地規模等について必要な规制をすることが でき，更に垣・柵の構造や樹林地の保存などにつ いても定めることができる。ただし，強制力には 一定の限界がある。

(3)道路，公園等の地区施設を定めることが可能と なる一拡幅すべき道路，新設すべき道路，公園等 について，予めその位置と規模を定めることがで きる。このことにより予定された道路，公園等の

集落地区計画と集落農振計画の関係

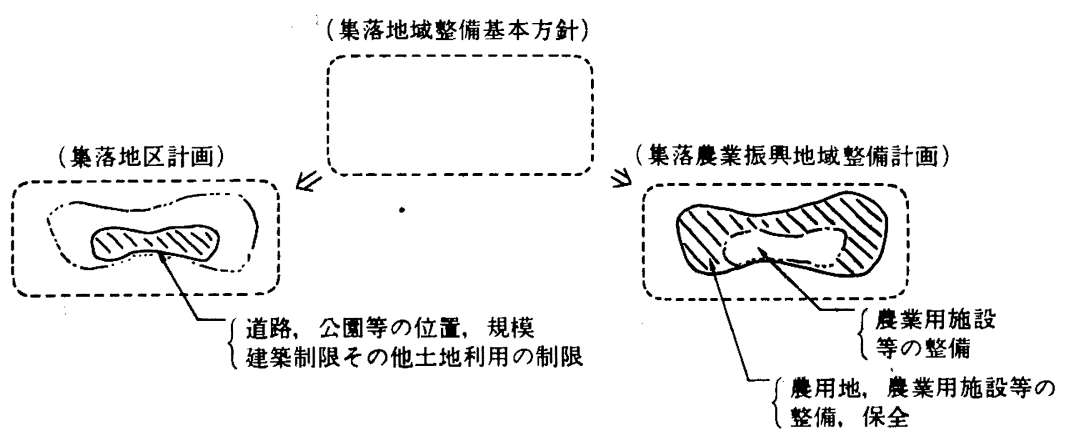


区域内に建築物等を建てることをチェックするこ とができる。これについても強制力には一定の限 界がある。

\section{III 集落地域整備法の問題点}

法施行後，日も浅く，功現実に法適用に至っ た集落がまだ存在しないことから，問題点はいま だ十分に出つくしてはいないが, 法案作成経過, および施行後のいくつかの具体地区における検討 を通じて問題と感じられた事項をまとめてみた w。

\section{1 対象となり得る集落の要件}

この法律の適用対象集落の要件は，まず法律に 於て都市計画区域と農業振興地域とが重複してい る区域に限定されている。これだけでも限定し過 ぎるという声も少なくないが，運用通達において は更に家屋が一定の集積状態にある集落でなけれ ばならないとしている。これは，調整区域の建前 から，特に前述のような对策の必要性の高い集落 にすべきだという考え方によっている。集落地区 計画に“ミニ市街化区域”の役割を持たせる以 上,こうした方向は避けがたいと考えられる。

将来の方向としては, “ミニ市街化区域”の意 味をもたない，単純な規制強化だけの手段（現行 の「地区計画」でよいと思われる）を調整区域内 にも一般的に適用できることとする必要がある。 家屋の集中しているエリアよりは，むしろ空港と 市街地を結ぶ道路の沿線とか高速道路のインター 周辺といった開発圧力の高い場所に適用すること が有効であり，また可能性も高いと思われる。

\section{2 集落地域の指定の方法}

前述のとおり，集落地域整備基本方針において 法適用集落がいわば「指定」される。これまでの 運用の考え方では，個々の集落の指定について建 設, 農水両大臣の承認が必要であり，かつその 際，国土庁はじめ関係省庁の協議が必要とされて いる。これは一市町村の中の極限定されたエリア である一集落の整備（それも特に周辺に強いイ
ンパクトを与える性格のものではない地区環境整 備）に, テクノポリスやリソート法に匹敵する手 続きが求められることを意味している。ルーチン 化してしまえば各省ともあまり注文はつけなくな ってそれほどの障害にはなるまいという見方もあ るが，あまりにもバランスが悪く制度の本旨に反 するものと考えられる。

法改正をするまでもなく，運用の工夫で対応で きる余地があると考えられるので，第一号の適用 までに両省での検討が望まれる。

\section{3 “ミニ線引き”に由来する問題}

集落地区計画を定めることが実質的には“ミニ 線引き”の意味あいを持つことに起因して，二つ の大きな問題を生じさせている。

第一は, 開発機会の平等性といった点である。 集落内を開発条件が大きく緩和される地区とそう でない地区とに再区分するわけであるから，各農 地所有者に利害の対立が生じる可能性が大きい。 この対立を解消する理想型としては, 開発を希望 する農地所有者の土地を土地改良事業による換地 によって農用地と非農用地に区分し，その非農用 地を集落地区計画の区域に配置する方法がある。 しかし，集落全体を巻き込む土地改良事業がまと まるのは容易ではないこと，また，すでに面整備 が完了している農地が大半である場合等, 同事業 の適用に必要な条件を有さない集落も考えられる こと等から,この理想型以外の利害調整方法をあ み出すことが求められている。

この場合, 集落地区計画のエリアがいくつかに 分割され得ると考えれば実践的な調整の可能性が 生じてくると考えられる。集落地区計画の区域は ミニ市街化区域のようなものであるので，ともす ると分割配置に否定的になりがちである。しか し，農村集落自体にも分散的な形態のものも少な くなく，一概に排除すべきではなかろう。この点 を弾力的に考えることができれば，各農地所有者 の転用希望地をべースとして一部交換分合もまじ えて配置の調整を行うことにより，飛び地型集落 地区計画を定めて利害調整，あるいは開発の機会 均等を確保することが相当程度可能となると考え られる。 
第二の問題は，集落地区計画の区域の面積規模 の齿止め論である。歯止めの必要性は，次の二つ の観点から主張される。

(1)調整区域の性格論一線引き制度の趣旨を崩し てはならないことは当然の前提である。したがっ て都市人口の受け血は市街化区域として整備すべ きであり，調整区域のまま行なわれる集落整備に おいては当該集落の維持・振興として必要な範讲 に限定して開発が認められるべきである。そうで なければ, 調整区域の性格が変質してしまうばか りでなく，いずれ本格的な基盤整備の必要が集落 内外に生じてきて公共投資面でも線引き制度が崩 れてしまうことになる。

(2)集落内スプロール防止論一調整区域内で許容 される開発行為等による集落環境の少化を防止す ることが主要な眼目である以上, 開発行為等を一 定のエリア内に限定していかざるを得ない。この エリアが無制限に広がるとすれば，結局，集落を 不動産屋的開発で食い謴すだけになってしまう。

それでは，何を齿止めの目安とすべきか。定量 化にはなお工夫が必要であろが, 安定的な菌止め 要素としては, 例えば次のようなものが考えられ る。

〈既存インフラのキャパシティ〉

集落地域整備法による開発は, あくまでも調整 区域の基本的性格を変質させないという前提の開 発であるとすれは，その開発に伴って大々的な公 共施設等のインフラストラクチャーの増強が必要 になるようなところまでは想定されていないとい うことになる。これを逆からいえば既存の（特段 の開発がなくても今後整備する必要がある場合 は，その整㣁後の）社会的インフラ（主要な道路 - 公園, 下水処理場, 上下水源の水量, 学校・病 院等の公益的施設）のキャパシティの籍囲内の開 発量に止めるべきだということになる。しかし， 実際には各インフラが一様に一定量の余裕がある
というようなことはないのでインフラのストック 全体を有効に生かしていくという梘点からの一部 施設の增強は許されよう。

〈既存コミュニティの許容限界〉

新制度の基本的目的は，既存の集落地域につい ての環境維持, あるいは地域社会の振興にあるこ とは、いくぶん表現は異なるが法の目的にうたわ れている。とすれば，既存集落のコミュニティの 秩序を破壊，または混乱させるような開発はチェ ックされなければならない。このことは，新開発 に主として量的な枠を示すことになる。すなわち 開発の結果その集落に流入することとなる世带な いし人口が少なくとも既存集落のそれを上回るこ とは許されない。“郷に入れば郷に従う”という ルールが維持されるために必要な歯止めが考えら れる。

〈既存集落の維持・振興にとって必要な開発で あるか否か

この視点は, 新規開発の質に関して一定の枠を 与える。たとえば，当該集落において将来発生す ろであろう内部宅地需要 (同居親族の独立=いわ ゆる分家に伴う住宅新築，一旦外部に出た者のU ターンに伴う住宅新築, 集落内の生活上, 生産活 動上必要な新規施設建設等）のために必要な宅地 開発は，正に集落の維持のためのものである。ま た例えば，当該集落に伝統的な地場産業があるよ うな場合に，その地場産業の振興のためにある種 の地域開発のプロジェクト（たとえば，木工の 村, 焼物の里, 織の町等々) は許容されるであろ う。更に例えば，専業でないにしても一定の土地 の耕作を行う者に限って分諆する宅地（クライン ガルテン付き住宅）の開発などもこの視点からで てこよう。これらの点については，その集落の条 件に即して検討すればいろいろな可能性があると 考えられる。 